\title{
Filling the Gap Between Heaven and Earth: One Building Two Sides
}

\author{
Sarah Marie Angne Alfaro \\ Ball State University, Indiana, USA
}

\begin{abstract}
In this paper, the meaning of various symbols and rituals threaded into sacred architecture are explored. Spatial dynamics, forms, and aesthetics are analyzed as a space transforms from a Protestant megachurch to a Catholic Cathedral. Featuring a case study of the Christ Cathedral, formally known as the Crystal Cathedral in Garden Grove, California, this research reveals how the act of worship is shaped by the architectural design in which it occurs. This study recognizes how stakeholders make sense of social, spatial, and spiritual components in a transitional place of worship; how the Protestant congregation and Catholic Diocese interact and how this transition effects the continuity of the Christian community. In this space, one building reveals two sides (formally Protestant, currently Catholic); the ritual sequencing, emblematic form, and symbolic aesthetics of the built form act as mediator of social practices of spiritual/religious practices of higher powers. Findings reveal ways that a physical place is designed to connect humans to their heavenly realms.
\end{abstract}

Keywords: sacred space, place transformation, environment and behavior

\section{Introduction}

Iconic architects of the past and present embrace the ethos that the environment surrounding the human is not merely the background, but the ever-present and integral presence of all the forces of life with which we are contained. The idea that we are not merely in nature, but of nature creates a powerful means of seeing the interaction of forms and forces in the world around us as the built environment is erected. For example, as an architect designs a building, it is not just a box placed upon a piece of ground, but a form which should emerge from its setting - the building and landscape as one. Built environments are references to something beyond themselves; they reflect the site that carries them, they reflect the culture they serve, and they are created and changed continuously by the way humans use them and the meanings humans attach to them.

As distinct building types emerge, power of the architecture heightens. It has been said, "architecture is the built form of ideas, and church architecture is the built form of theology" (McNamara, 2014, para. 3). Eero Saarinen (1962) explained,

Now, what is the purpose of architecture? ... I believe it has a much more fundamental role to play for man, almost a religious one. Man is on earth for a very short time and he is not quite sure what his purpose is. Religion gives him his primary purpose. The permanence and beauty and meaningfulness of his surroundings give him confidence and a sense of continuity. So, to the question, what is the purpose of architecture, I would answer: To shelter and enhance man's life on earth and to fulfill his belief in the nobility of his existence. (p. 5)

Sarah Marie Angne Alfaro, Ph.D., assistant professor, Department of Construction Management and Interior Design, Ball State University, Indiana, USA. 
Churches, cathedrals, synagogues, mosques, temples, and shrines are "reflections of the spiritual narratives embraced by particular religious groups" (Vosko, 2014, para. 2). "Religion endows these places with symbolic meaning which not only help differentiate them from ordinary spaces" (Najafi \& Shariff, 2014, para. 2), but through their geography, design, and aesthetics, they have the capacity to also foster attachment, devotion, and spirituality, and establish disposition, ethos, and worldview in those who enter (S. Mazumdar \& Sh. Mazumdar, 2004).

There is an integral trichotomic relationship between man, place, and religion. Religion and communal rituals carried out by man, in a physical setting filled with symbolism can create a sense of place and spiritual experience and foster closeness to that which they seek (Barrie, 2010). Spatial sequencing within sacred architecture can serve to connect humans to a higher power. Forms explicate meaning in sacred architecture to connect humans to the omniscient. Aesthetics within sacred architecture, specifically materiality and art, help cultivate a middle ground between humans, bringing that closer to that which they worship. The life that takes place in built forms constructs and frames meaning. The frame is like a mirror or a picture and the humans' everyday life can be seen in this frame. Dovey (1999) described secular built forms acting as mediators of social practices of power. The power of sacred architecture is multivalent and there is a strong two-way connection between the design of a space and the emotions experienced by people in the space including the "sense of other" or "higher power" (Tuan, 1977).

Featuring a case study of the Christ Cathedral, formally known as the Crystal Cathedral in Garden Grove, California, this research reveals how the act of worship is shaped by the architectural design in which it occurs. In this space, one building reveals two sides (formally Protestant, currently Catholic); the ritual sequencing, emblematic form, and symbolic aesthetics of the built form act as mediator of social practices of spiritual/religious practices of higher powers.

Communal rituals are a means to broaden our engagements with the built environment (Barrie, 2010). Due to the actions performed within places by humans, they become significant (White, 2003). Wescoat and Ousterhout (2012) explained architecture does not merely host events; rather it magnifies and elevates them through the human interaction and rituals facilitated within. Rituals inserted into places, when conducted and paired with religion, evoke sacredness and a person's identification with the place is solidified (S. Mazumdar \& Sh. Mazumdar, 2004). Through a series of deliberate and sequential moves, architecture can set out to dissolve the spiritual boundaries between man and the divine.

Specific forms explicate meaning in sacred architecture as means to connect humans to the omniscient. The shape of the church and architectural forms within both the east and west early Christian church, were built to mediate the worshipper between heaven and earth; thus, central forms of sacred architecture are symbolic to the way those in the space interact with the God they worship.

Symbols provide a sign language depicting that which cannot be represented in visible form (White, 2003). Jung (1968) explained, "Because there are innumerable things beyond the range of human understanding, we constantly use symbolic terms to represent concepts that we can't define or fully comprehend. This is one reason why all religions employ symbolic language or images" (p. 4). Symbols provide references to a more extraordinary realm of possibility that often defies rational explanation (Vosko, 2014). Through identification with a symbolic meaning in the built environment, people attain a sense of belonging to a group of people or a sense of place. It is the layering of the architecture, with the religion's symbolism and rituals, as well as the meaning and sense of place that is established, that serves as a way to link humans to that which they seek, revere, fear, and worship (Jones, 2000). 
The aesthetics within sacred architecture, through materiality and art within the built environment, form a middle ground that mediates between humans and that which they worship. Art forms, mosaics, tapestries, as well as materials built into the space, such as stone or glass are symbolic in that through these aesthetic-the walls begin to teach alongside the religious leaders. Other aesthetic techniques are used to portray symbolism in art with sacred architecture that mediates between the devotee and their God. Whether literal or abstract, these outward signs of the inward and spiritual divine are used in the aesthetics of many sacred architectural buildings and are interpreted by humans and used as means to connect to the divine.

\section{The Legendary Crystal Cathedral}

The Crystal Cathedral was part of the Reformed Church in America, located in Garden Grove, California. Well-known for its spectacle, the "possibility thinking theologian" Reverend Dr. Robert H. Schuller believed for the space in the late 70's while working alongside the legendary architects Philip Johnson and John Burgee of Johnson/Burgee architectural firm from New York. Groundbreaking for the building began December 4, 1977 and on September 14, 1980 the building was dedicated. The space served as a television set for the "Hour of Power", a weekly world-wide televised sermon. The accolades for the church were astounding. In 2004, as Time Inc. published a book titled Great Buildings of the World, The World's Most Influential, Inspiring, and Astonishing Structures. Within this book, architecture marvels included the Ancient Pyramids, the Taj Mahal, the Parthenon, Paris Opera House, and the Empire State Building. Five notable Christian structures made the list including the Crystal Cathedral in Orange County California which sat among the great Michelangelo's Basilica of St. Peter in Rome, St. Basils Cathedral in Russia, St. Mark's Basilica in Italy, Chartres Cathedral in France.

As guests walked through the Protestant's Crystal Cathedral doors, the three entrances were strategically positioned under sloped balconies hovering just seven-and-a-half feet from the front girder overhead. This served as a compression that prepared the visitor for the expansion to come. Once inside, as the guest stepped closer toward the center of the Cathedral, the balcony's overhead ended and the Cathedral's expansive scale, glass and lattice work rose 12-story. From every angle, views of the surrounding Southern California landscape and sky are seen. Twelve water fountains ran the length of the center aisle on the main floor representing the twelve Apostles, "these fountains danced their praise during the opening and closing of each Sunday service, wedding, or special occasion" (Crystal Cathedral Ministries, 2004, p. 39). The chancel, at the north end of the fountain, was 185 feet long and constructed out of Rosso Alicante marble. The three pulpit sections of marble had been symbolically interpreted as communion chalices, angel wings, a heart, or Christ on the cross with a crucified thief. Others, symbolically realizing that the marble had been forming for millennia deep inside the earth, would see both the design and their inclusion inside the Cathedral as providential (Crystal Cathedral Ministries, 2004, p. 68). Promotionally speaking, the marble became an excellent setting for the weekly Hour of Power television show; in some areas, wood was painted to look like marble to emphasize the grandeur. Behind the chancel were two 90-feet tall doors controlled electronically. These doors created a direct connection with nature as guests felt the Southern California breeze, and even at times witnessed a flock of birds fly through. When the opening note at the start of a service was played on the large organ, the choir harmoniously sung along, a breeze from the large doors flooded the sanctuary and the fountains in the center rose in a breath-taking moment. The aesthetics of the architecture were designed for humans who desired an encounter with something more. Guests and visitors alike explain, in a reoccurring theme over the course of many interviews, how the 
aesthetic details of the Crystal Cathedral, centered on nature, heightened their connection they had with a higher power while in the space:

Informant 1: [walking into the space from compression to expansion through transparent glass] "The Heavens just opened up!"

Informant 2: [as the doors opened and the breeze was felt] "It was like a breath from the Holy Spirit"

Informant: 3: "The best view is at the very top of the west balcony, here you gain eternal perspective" [due to the expansive glass view and perspective lines]

As the Crystal Cathedral congregation worshipped, the glass opened those who were inside to the nature outside with the desire for those interacting to establish a connection to the heavens above. The originator behind the Cathedral, Revered Dr. Robert H. Schuller vision for the space was, "Once inside the Crystal Cathedral your life is like a window to let God's light shine in and let the glory reflect into the world" (Robles-Anderson, 2012). His personal passion and inspiration from nature came from his childhood as he grew up on an Iowa farm and developed fond memories of the sky, clouds, streams, trees, and birds (Schuller, 2005). This upbringing paired with his training while designing with architect Richard Neutra on previous projects helped him understand the tranquilizing system that triggered response to a person by nature. This was then relayed and carried into the Crystal Cathedral by Philip Johnson and John Burgee. Using "biorealism", architecture that is shaped by the biology of the creature that will reside in the structure, allowed those inside the space a glimpse into that which they worshiped. Ingham (2005) also discovered that a large quantity of natural light and feeling a connection with nature, either through materials used or actual views, aided feelings of meaning in church sanctuaries. Antonio Gaudi pronounced it best, "If nature is the work of God, and if architectural forms are derived from nature, then the best way to honor God is to design buildings based on His work" (Berlin, 2010).

\section{Transformation to Christ Cathedral}

In 2000, at the age of 80, Reverend Dr. Robert H. Schuller stepped off the platform and his son Robert A. Schuller, took stage. On January 22, 2006, Robert A. assumed the role of senior pastor of the Crystal Cathedral, and for two years, he held that position. Suddenly, in 2010, Sheila Schuller Coleman, daughter of Reverend Robert H. Schuller, was appointed as the lead pastor of the Crystal Cathedral, officially taking the reins from her brother and father. However, in October of 2010, after battling financial difficulties for several years, Crystal Cathedral Ministries declared bankruptcy.

After filing bankruptcy, the church was sold to the Roman Catholic Diocese of Orange. In February 2012, the Roman Catholic Diocese of Orange agreed the Crystal Cathedral Ministry had three years to find a new home. Ultimately, the Crystal Cathedral congregation moved a few miles away and changed their congregation name. Shepherd's Grove, the newly appointed name, became the new home for church services, weekly activities, and the internationally televised Hour of Power. Bobby Schuller, Reverend Dr. Robert H. Schuller's grandson, Robert A.'s son and Sheila Schuller Coleman nephew, assumed the new pastoral role for the ministry and the face of continued Hour of Power from the new location.

The Catholic Diocese of Orange remade their newly acquired building the Christ Cathedral. As the transition occurred the stakeholders, while planning for suitable renovations, realized there was a sacredness to the existing site. They understood the power of the preceding ministry, and made distinct connections about the contributions from the past which would impact the future Cathedral. They sought to respect the past, striving 
to preserve the architectural beauty and with empathy towards the memories many people held of the past. However, the focus of the Catholic's new Christ Cathedral was to provide the optimum environment for Catholic worship, liturgical worships-not watching something (as in the Crystal Cathedral) but participating in an action - and so taking the various liturgical rights and talking about how one can shape the space around it so that the way the space is designed, and appointed, are arranged to allow the fullest expression of the liturgy.

Leaning on the guiding documents: Sacrosanctum Concilium, Environment and Art in Catholic Worship, and Built of Living Stones: Art, Architecture, and Worship, the stakeholders began designing the future of the space. They first established their views in the "modern [Catholic architecture] camp", this opposed by many in the "classical [Catholic architecture] camp". Then, they began to design in more authenticity. They understood the previous ministry as "low liturgy" and wanted to "add liturgy back in". The stakeholders explained,

One of the things we need to be very careful about is the Catholic liturgy is not there to entertain; and televangelism (from the previous Crystal Cathedral ministry), in many respects, the style of worship, is the entertainment style of worship.

The sacraments-religious rituals like the Mass and confession-were the main means of human contact with the divine.

The new redesigned site would involve sacred space impressions and specific thresholds from the procession from the "profane" car/parking lot into the "scared" Cathedral. They desired to maintain the existing architecture, however, the interior space planning revolved around the altar location. They wanted to enhance the beauty by building in opportunities focused on verticality, natural materials, directionality, as well as iconography and symbolism. The exterior glass panels were covered by quatrefoil panels with lights behind and thought of ethereal, "lighting from the unseen". As they considered technology, they wanted to "sanctify it". They were careful that no Jumbotron (from the previous Crystal Cathedral ministry) would take dominance, but the use of technology would be used to enhance communication (i.e., those with hearing impairments, to connect those with language barriers, etc.). The embellishments the social actors designed into their Cathedral afforded ways participants could bridge across the physical space to the spiritual realm. The saints, like Mary, the mother of Jesus, were holy people held up as examples by the church, called upon in prayer to "intercede" for Catholics with the Father and the Son. As they designed they held a, "posture of reverence to the Lord" and were accountable financially to the Diocese and to the civic community stating, "We're building 'a' church and we're building 'the' church".

\section{Conclusions}

As the Protestant's Crystal Cathedral becomes a Catholic's Christ Cathedral the built form encourages a deeper understanding of place formation, our presence in space, and the roles on human life. The Crystal Cathedral offered a connotative space with vague sequencing, emblematic form, and symbolic aesthetic. The open, abstract environment, focused on nature in order to connect to God. The modern building was revolutionary when built and legendary as a memory.

As the Christ Cathedral emerges, the building has a historical precedent. The reused and nearing historic building is evolutional. The new design leans to a described and defined denotative impression. The insertion of thresholds, examination of rituals, and the addition of symbols, sacramental art via materials and lighting applications defined and designed by social actors, intend to enhance the spiritual environment and become 
highly representational. Striving to make the space more "authentically Catholic", the social actors are reinforcing the role of decorative arts in the life of the Catholic Church.

This study recognizes how stakeholders make sense of social, spatial, and spiritual components in a transitional place of worship; how the Protestant congregation and Catholic Diocese interact and how this transition effects the continuity of the Christian community. Through the meaning of various symbols and rituals threaded into sacred architecture, spatial dynamics, forms, and aesthetics reveal ways that a physical place is designed to connect humans to their heavenly realms.

\section{References}

Barrie, T. (2010). The sacred in-between: The mediating roles of architecture. New York: Routledge.

Berlin. (2010). Gaudí's masterpiece. National Geographic Magazine. Retrieved from http://ngm.nationalgeographic.com/print/ 2010/12/big-idea/gaudi-text

Crystal Cathedral Ministries. (2004). Visitor center handbook. Garden Grove, California.

Dovey, K. (1999). Framing places: Mediating power in built form. New York: Routledge.

Ingham, D. (2005). Experiencing meaning in two Presbyterian churches: A qualitative analysis. Columbia, MO: Architectural Studies.

Jones, L. (2000). The hermeneutics of sacred architecture: Experience, interpretation, comparison (Vol. 1). Massachusetts: Harvard University Press.

Jung, C. (1968). Man and his symbols. New York: Dell Publishing Co. Inc.

Mazumdar, S., \& Mazumdar, Sh. (2004). Religion and place attachment: A study of sacred places. Journal of Environmental Psychology, 24(3), 358-397.

McNamara, D. (2014). Built form of theology: The natural sympathies of Catholicism and classicism. The Institute of Sacred Architecture. Retrieved from http://www.sacredarchitecture.org/articles/built_form_of_theology/

Najafi, M., \& Shariff, M. K. (2014). Public attachment to religious places: A study of place attachment to mosques in Malaysia. International Journal of Social, Management, Economics and Business Engineering, 8(1), 299-310.

Robles-Anderson, E. (2012). The crystal cathedral: Architecture for mediated congregation. Public Culture, 24(3). Retrieved from http://www.publicculture.org/articles/view/24/3/the-crystal-cathedral-architecture-for-mediated-congregation

Saarinen, A. (1962). Eero Saarinen on his work. Connecticut: Yale University Press.

Schuller, R. H. (2005). A place of beauty, a joy forever. California: Crystal Cathedral Ministries.

Tuan, Y. F. (1977). Space and place: The perspective of experience. Minnesota: University of Minnesota Press.

Vosko, R. (2014). The search for symbolism in religious architecture. The American Institute of Architects. Retrieved from http://www.aia.org/practicing/groups/kc/aiab081076

Wescoat, B., \& Ousterhout, R. (2012). Architecture of the sacred space, ritual, and experience from classical Greece to Byzantium. New York: Cambridge University Press.

White, J. (2003). Protestant worship and church architecture: Theological and historical considerations. Oregon: Stock Publishers. 